\title{
Testicular development and maturation of the hypothalamic-pituitary-testicular axis in the male tammar, Macropus eugenii
}

\author{
P. Williamson*, T. P. Fletcher $\dagger$ and M. B. Renfree $\dagger$ \\ *School of Veterinary Studies, Murdoch University, Murdoch, WA 6150, Australia; and \\ †Department of Anatomy, Monash University, Melbourne 3168, Victoria, Australia
}

\begin{abstract}
Summary. Testicular growth and maturation of the hypothalamic-pituitary-testicular axis were assessed in male tammars from 12 to 25 months of age to establish the time of sexual maturity. The testicular dimensions and body weights of 20 male tammars, $\sim 12$ months of age at the beginning of the study, were measured monthly for I year. Groups of 3 animals were castrated at 13,19 and 25 months of age and their testes sectioned for histological examination. Testicular volume increased between 12 and 24 months of age and was highly correlated with body weight $(r=0.91)$. In the 13-month group the seminiferous tubules were closed with few mitotic figures. Spermatogenesis had begun in 2 of the 19-month animals. All stages of spermatogenesis were present in the other 19-month male, and in all of the 25-month males.

Basal FSH concentrations increased with the age of the animal $(21.0 \pm 32 \cdot 48$, $94.40 \pm 55.18$ and $193.05 \pm 40.21 \mathrm{ng} / \mathrm{ml}$ (mean \pm s.d.) at 19,20 and 25 months respectively) while basal $\mathrm{LH}$ concentrations were similar at 20 months and 25 months $(0.43 \pm 0.18$ and $0.58 \pm 0.25 \mathrm{ng} / \mathrm{ml}$ respectively). Basal testosterone concentrations were also similar $0.11 \pm 0.04,0.35 \pm 0.16$ and $0.22 \pm 0.10 \mathrm{ng} / \mathrm{ml}$ in $13-, 19-$ and 25-month-old animals.

LHRH injection in tammars at 13,19 and 25 months of age induced release of both $\mathrm{LH}$ and testosterone $10-30 \mathrm{~min}$ after injection. The hormone concentrations increased in both magnitude and duration with increasing age. At 13, 19 and 25 months, peak testosterone values of $1.13 \pm 0.27,1.90 \pm 0.45$ and $6.58 \pm 0.91 \mathrm{ng} / \mathrm{ml}$ (mean \pm s.d.), respectively, were measured by $90-120 \mathrm{~min}$ after injection and peak $\mathrm{LH}$ values at 13 , 19,20 and 25 months of age were $2 \cdot 46 \pm 0 \cdot 82,8 \cdot 31 \pm 2 \cdot 02,9 \cdot 0 \pm 2 \cdot 18$ and $7.86 \pm 1.41 \mathrm{ng} / \mathrm{ml}$, respectively, when measured $30 \mathrm{~min}$ after injection. By contrast, LHRH injection did not increase FSH concentration at 20 or 25 months of age above the basal concentration.
\end{abstract}

Taken together, the morphological and endocrinological data show that puberty in male tammars begins around 19 months and is complete by 25 months of age.

Keywords: testis, testosterone; LH; FSH; LHRH; spermatogenesis; marsupial; puberty

\section{Introduction}

Bronson \& Risman (1986) pointed out that puberty in mammals is not a single event occurring at one time, but is an acceleration of developmental processes that have been under way since the start of sexual differentiation, and that no one so far has been able to define this sequence of events in a way that accounts for differences between the sexes and mammalian species. For these reasons, we have defined puberty in the male tammar as the time of commencement of production of gametes, as assessed morphologically, and when changes occur in the endocrine system consistent with 
maturation of the hypothalamic-pituitary-testicular axis. Sexual maturity is attained only when the male can successfully fertilize a female.

Growth and maturation of the testis in man, primates, bulls, rams and rats are acutely dependent on stimulation by pituitary gonadotrophins (Ojeda \& Urbanski, 1988; Plant, 1988; Spratt \& Crowley, 1988; Schanbacher, 1982; Lee et al., 1981). The stimulation of increased circulating levels of luteinizing hormone $(\mathrm{LH})$ and follicle-stimulating hormone (FSH) by synthetic luteinizing hormone-releasing hormone (LHRH) administration is widely used in clinical and experimental studies of pituitary function (Berger et al., 1981; Lee et al., 1981; Rosendahl et al., 1984; Arslan et al., 1986; Spratt \& Crowley, 1988), and is also a good index of the change in responsiveness of the hypophysial-gonadal axis from the time of birth to sexual maturity.

The gonads of the male tammar wallaby (Macropus eugenii) have differentiated by Day 2 post partum (Renfree et al., 1987; Short et al., 1988; O et al., 1988; Shaw et al., 1989) and testicular development shows logarithmic growth throughout the 8 months of pouch life (Alcorn, 1976). From a longitudinal study of a wild population of tammars, Inns (1982) considered that sexual maturity is reached at $18-20$ months of age, when the testes enlarge rapidly, the seminiferous tubules open and spermatozoa are produced. Lincoln (1978) has reported that a marked surge in plasma testosterone concentrations occurred within $90 \mathrm{~min}$ of the intravenous administration of synthetic LHRH to mature male tammars, but the changing response of testosterone, $\mathrm{LH}$ and FSH in male marsupials to LHRH injection at puberty has not been studied. In the present study testicular growth and the maturation of the hypothalamic-pituitary-testicular axis, as measured by the response to LHRH injection before and after onset of spermatogenesis, were examined in juvenile, subadult and adult tammar wallabies.

\section{Materials and Methods}

\section{Testicular development}

The testicular dimensions and body weights of 20 male tammar wallabies (Macropus eugenii), approximately 12 months of age at the beginning of the study, were measured monthly for 1 year, commencing in February. Testicular dimensions were transformed to give the volume of each testis using the formula for an oblate sphere, $V=\pi / 6 . W^{2} \mathrm{~L}$, where $\mathrm{V}=$ volume, $\mathrm{W}=$ width of the testis and $\mathrm{L}=$ length of the testis excluding the epididymis. The animals were kept in an enclosure, adjacent to mature female tammars, and fed oats and lucerne hay ad libitum.

\section{LHRH response and the onset of spermatogenesis}

Experiment 1. Plasma hormone concentrations following a single intravenous injection of $10 \mu \mathrm{g}$ synthetic LHRH (Relefact, Hoechst, Sydney, Australia) were measured in 3 groups of male tammars at different stages of testicular development, approximately 13 months ( 4 animals), 19 months ( 4 animals) and 25 months ( 3 animals) of age at the time of treatment.

Tammars were fasted overnight and cannulae (Silastic, Dow Corning, Midland, MI, USA; 0.3 in i.d., 0.65 in o.d.) were inserted into a jugular vein under anaesthesia induced by pentobarbitone sodium $(60 \mathrm{mg} / \mathrm{ml}$ to effect; Abbott, Sydney, Australia) and maintained by halothane (Fluothane, ICI, Australia). After recovery the wallabies were caged individually for 1 week until LHRH administration. Heparinized blood $(5 \mathrm{ml})$ was collected from the wallabies $40 \mathrm{~min}, 20 \mathrm{~min}$ and immediately before the rapid intravenous injection of $10 \mu \mathrm{g}$ synthetic LHRH, and 10,30,50, 70, 90,110 and $180 \mathrm{~min}$ after LHRH administration, and on several occasions during the following week. Plasma was decanted immediately and stored at $-20^{\circ} \mathrm{C}$ until assayed for testosterone and, when possible, for $\mathrm{LH}$ and FSH. Some plasma samples from the older groups were lost during storage, before LH and FSH assays could be performed. The LHRH challenge was repeated to furnish plasma for these assays in peripubertal and mature animals (Exp. 2). The animals were then castrated under anaesthesia and samples of testis and epididymis were fixed in Bouin's fluid, sectioned at $8 \mu \mathrm{m}$ and stained with haematoxylin-eosin and periodic acid-Schiff reagent. The mean diameter of testicular tubules in the different age groups was calculated from measurements taken with a micrometer eye-piece of the diameter of 12 tubules, cut in cross-section, in sections from each of 3 tammars in each age group. One wallaby was injected with LHRH at 18 months of age and after the serial bleedings the cannula was removed and the wallaby returned to the open yard. At 25 months of age this tammar was again cannulated, given LHRH, serially bled and then castrated.

Experiment 2. Three additional mature male tammars ( 25 months of age) and 3 peripubertal males ( 20 months of age) were fitted with an indwelling catheter (Terumo) in the lateral tail veins and caged individually. Heparinized 


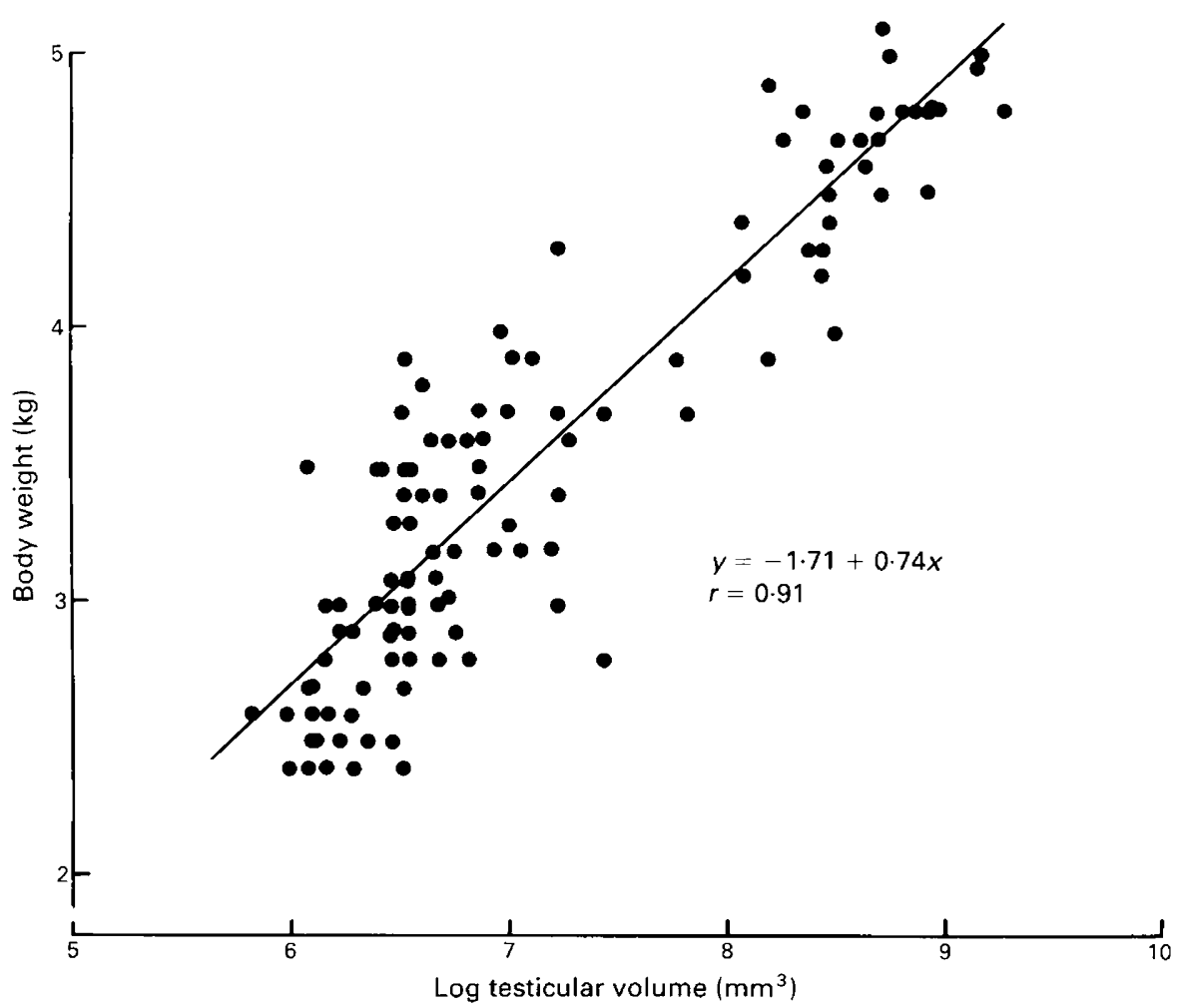

Fig. 1. The body weight of tammars plotted against the natural logarithm of testicular volume.

blood ( $2 \mathrm{ml}$ ) was collected from each tammar at the same times before and after the injection of $10 \mu \mathrm{g}$ synthetic LHRH as in Exp. 1. The catheter was flushed with $100 \mu \mathrm{l}$ heparinized saline solution $(125 \mathrm{IU} / \mathrm{ml})$ after each sample was taken. The blood was centrifuged and the plasma was decanted and stored at $-20^{\circ} \mathrm{C}$ until assayed. After the last blood sample was taken the catheters were withdrawn and the animals injected intramuscularly with $1 \mathrm{ml}$ Duplocillin (Intervet) then released into outdoor pens. The plasma samples were assayed for LH and FSH by radioimmunoassay (RIA).

\section{Hormone assays}

Testosterone. Testosterone concentrations in plasma samples were measured by the radioimmunoassay of Sumbung et al. (1987) for plasma androgens, but without separation of the steroid fractions over celite columns. The antiserum sheep anti-testosterone (6050), prepared using a testosterone-3-carboxymethyloxine-BSA antigen was provided by Dr R. I. Cox, CSIRO Division of Animal Production, Prospect, NSW, Australia. The antiserum had cross-reactivity of $31 \%$ with $5 \alpha$-dihydrotestosterone (DHT) and $30 \%$ with 4 -androsten-3 $3,17 \beta$-diol, but less than $5 \%$ cross-reactivity with all other steroids tested. Catling \& Sutherland (1980) found that over $80 \%$ of the total androgen activity in tammar plasma was eluted in the testosterone peak after chromatography on Sephadex LH20 columns. They used antiserum S-741 in their testosterone RIA which had a cross-reaction of $100 \%$ with testosterone and DHT

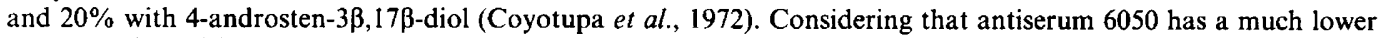
cross-reaction with DHT, we conclude that the immunoreactive androgen measured in the present study was testosterone. The efficiency of extraction of $\left[{ }^{3} \mathrm{H}\right]$ testosterone from $100 \mu l$ plasma by $1.5 \mathrm{ml}$ diethyl ether was $78.9 \%$ and assay sensitivity was $80 \mathrm{pg} / \mathrm{ml}$. Serial dilutions of testosterone in plasma from a castrated tammar were assayed and yielded a significant correlation between expected and assay results $(r=0.89, P<0.01)$. Triplicate aliquants of a plasma sample with a mean testosterone level of $437 \mathrm{pg} / \mathrm{ml}$ was run in each assay, and the results pooled to calculate the inter-assay coefficient of variation $(17 \cdot 2 \%)$. Intra-assay coefficient of variation was $3 \cdot 86 \%$.

$\boldsymbol{L H}$. LH was measured by the heterologous double-antibody radioimmunoassay described by Sutherland $e t$ al. (1980) and validated for use with tammar plasma. The radioligand was NIADDK rat LH-16 and the antibody was rabbit antiovine LH (GDN-15) purchased from Professor G. D. Niswender, Colorado State University, Fort Collins, CO, USA. The standard was NIH-oLH-S23. The assay sensitivity was $0.3 \mathrm{ng} / \mathrm{ml}$ and intra-assay coefficient of variation was $4.5 \%$. All samples were measured in the same assay. 


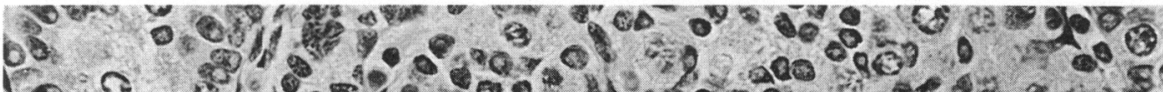

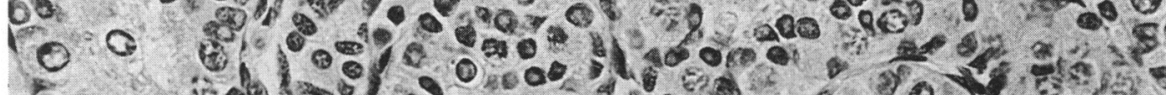

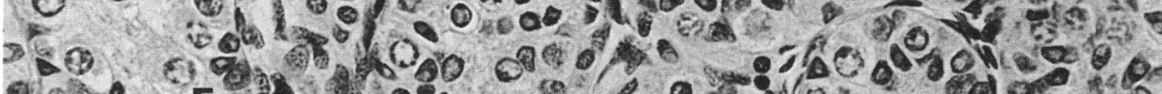

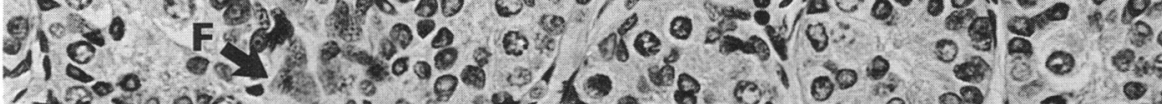

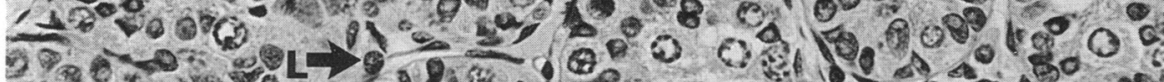

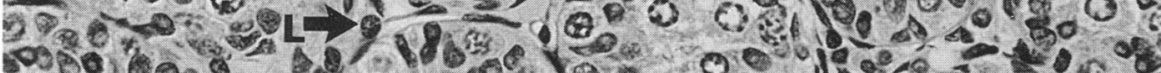

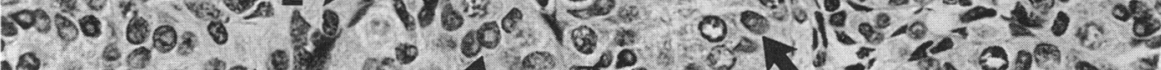

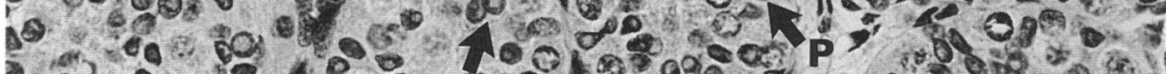

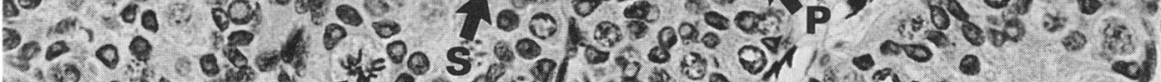

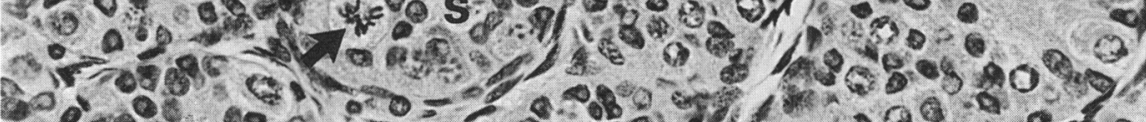

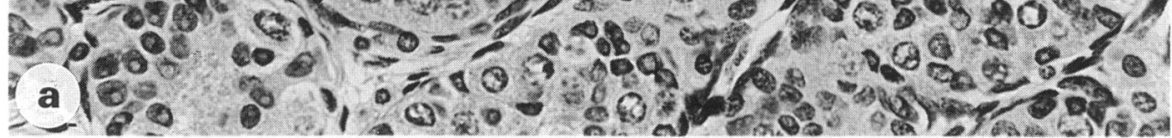

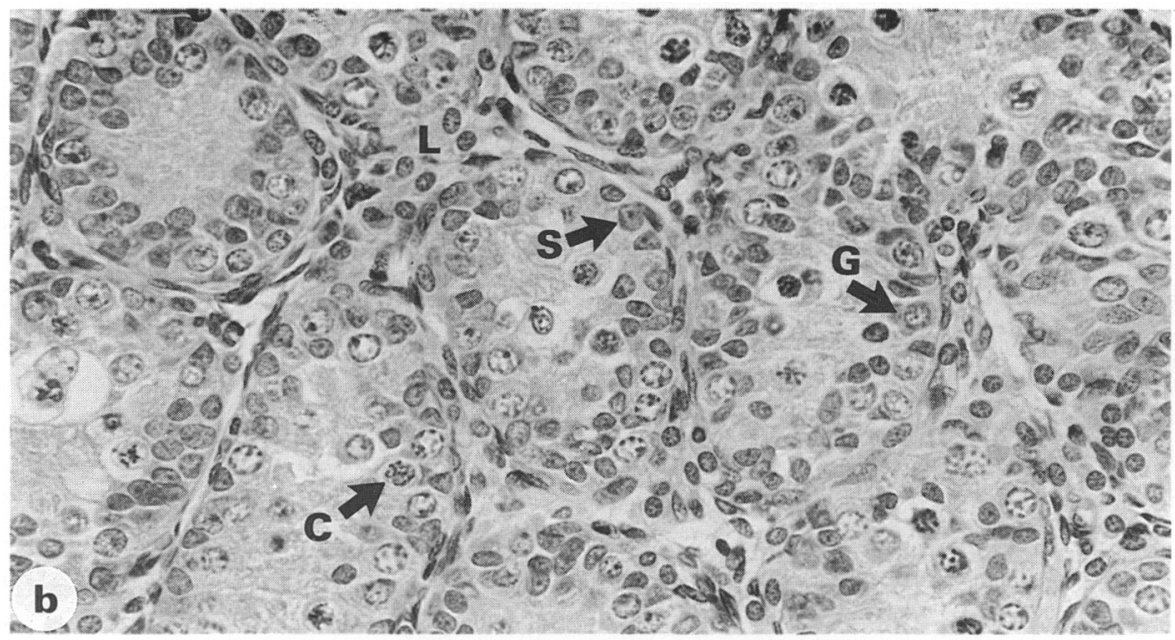

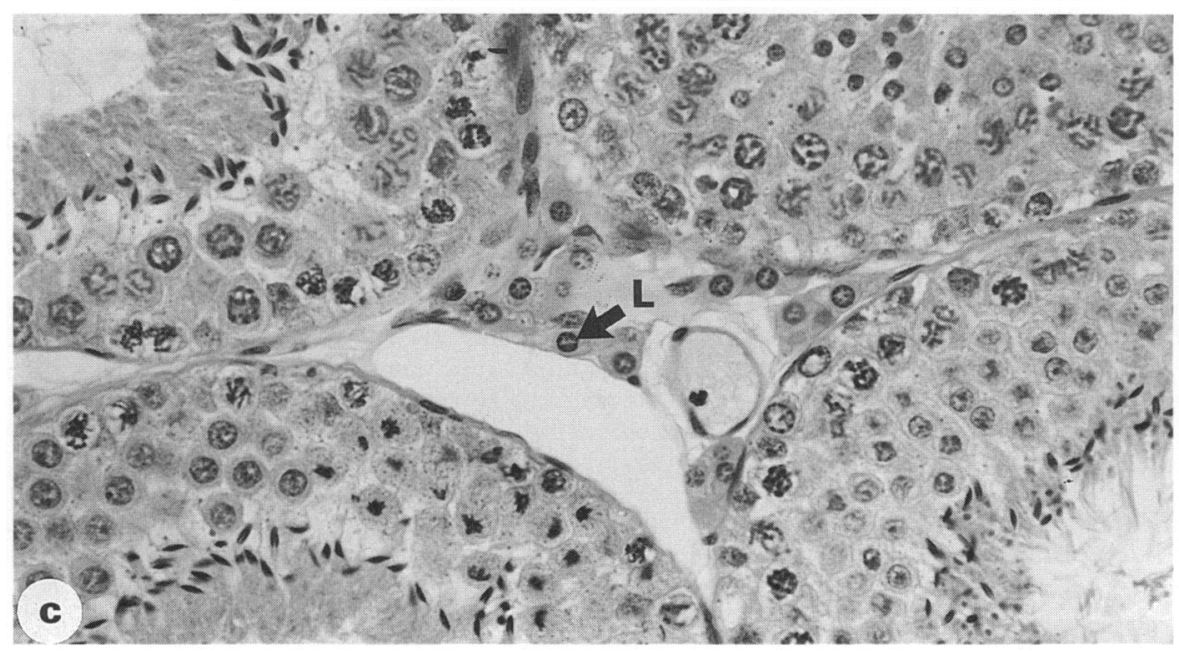


FSH. FSH was measured by the heterologous double-antibody radioimmunoassay described by Evans et al. (1980) and validated for use with tammar plasma. The radioligand was rat FSH I-6 and the antibody was rabbit antiovine H.31 obtained from NIH National Hormone \& Pituitary Program, Bethesda, MD, USA. The standard was NIH-oFSH-S13. The assay sensitivity was $5 \mathrm{ng} / \mathrm{ml}$ and intra-assay coefficient of variation was $6.05 \%$. All samples were measured in a single assay.

\section{Results}

\section{Testicular growth rate}

The regression of body weight against the natural logarithm of testicular volume is shown in Fig. 1. The testicular growth curve is described by the regression equation $y=1 \cdot 71+0 \cdot 74 x$, where $y=$ body weight and $x=$ natural logarithm of the testicular volume, with a correlation coefficient of 0.91 .

\section{Histology of the testes}

Males at 13 months of age. Males in this age group were clearly immature (Fig. 2a). The seminiferous tubules were without a central lumen and had a mean ( \pm s.d.) diameter of $66 \pm 6 \mu \mathrm{m}$. They contained two main cell types: supporting cells, which are precursors of Sertoli cells, and prespermatogonia. A few gonocytes, from which the pre-spermatogonia develop, were present in the centre of the tubules. The interstitial tissue contained many fibroblasts and some mature Leydig cells with granular cytoplasm. There were few mitotic figures in the tubules or interstitial tissue, and no spermatozoa in sections of the head and tail of the epididymides.

Males at 19 months of age. Tammars in this group were sub-adult (Fig. 2b). In 2 of the 3 tammars spermatogenesis had been initiated, but not all stages were present (Fig. 2b). The seminiferous tubules were lined with Sertoli cells, spermatogonia and primary spermatocytes. The mean ( \pm s.d.) diameters of the seminiferous tubules of these wallabies were $151 \pm 15 \mu \mathrm{m}$ and $91 \pm 9 \mu \mathrm{m}$ respectively. Mitotic activity was evident in the germinal epithelium. The interstitial tissue contained clumps of mature Leydig cells, and fewer undifferentiated fibroblasts than did the testes of the 13-month-old wallabies. There were no spermatozoa in the epididymides. By contrast, all stages of spermatogenesis were present in the germinal epithelium of the third wallaby. Spermatozoa were present in the caput and cauda epididymidis and small groups of mature Leydig cells were present in the interstitial tissue. The mean ( \pm s.d.) diameter of the seminiferous tubules was $201 \pm 15 \mu \mathrm{m}$.

Males at 25 months of age. These tammars were classified as fully mature (Fig. 2c). All stages of spermatogenesis were present in testicular sections from each wallaby. The seminiferous tubules measured $210 \pm 19 \mu \mathrm{m}$ (mean \pm s.d.) in diameter, with mature Leydig cells being the predominant cell type in the interstitial tissue.

\section{Response to LHRH injection}

Experiment 1. The resting (basal) plasma testosterone concentrations (mean \pm s.d.) of the different age groups were similar $0.11 \pm 0.04,0.35 \pm 0.16$ and $0.22 \pm 0.10 \mathrm{ng} / \mathrm{ml}$ in $13-, 19-$ and

Fig. 2. Photomicrographs of testicular tubules from tammars of different ages. $\mathrm{H}$ and $\mathrm{E}, \times 380$. (a) Immature tammar at 13 months of age showing fibroblasts (F) and Leydig cells (L) in the interstitial tissue and Sertoli cells $(\mathrm{S})$ and prespermatogonia $(\mathrm{P})$ in the tubules. Mitotic figure (arrowed) is a dividing prespermatogonium. (b) Tammar at 19 months showing Sertoli cells (S), spermatogonia $(\mathrm{G})$ and spermatocytes $(\mathrm{C})$ in the tubules. Leydig cells $(\mathrm{L})$ are the predominant cell type in the interstitial tissue. (c) Mature tammar at 25 months. All stages of spermatogenesis are present. Clumps of mature Leydig cells $(\mathrm{L})$ are in the interstitial tissue. 
25-month animals respectively (Fig. 3a). All animals showed increased concentrations of testosterone in plasma 10-30 min after the LHRH injection. The 13- and 19-month-old animals had mean peak testosterone values of $1.13 \pm 0.27$ and $1.90 \pm 0.45 \mathrm{ng} / \mathrm{ml}$ respectively, $60-80 \mathrm{~min}$ after LHRH injection, but the 25 -month-old males had much higher peak values $(6.58 \pm 0.91 \mathrm{ng} / \mathrm{ml}) 90$ $120 \mathrm{~min}$ after LHRH injection. The increased testosterone concentrations persisted longer in the 25-month-old animals and did not return to pre-injection concentrations by 7 days after injection when the last blood samples were taken.
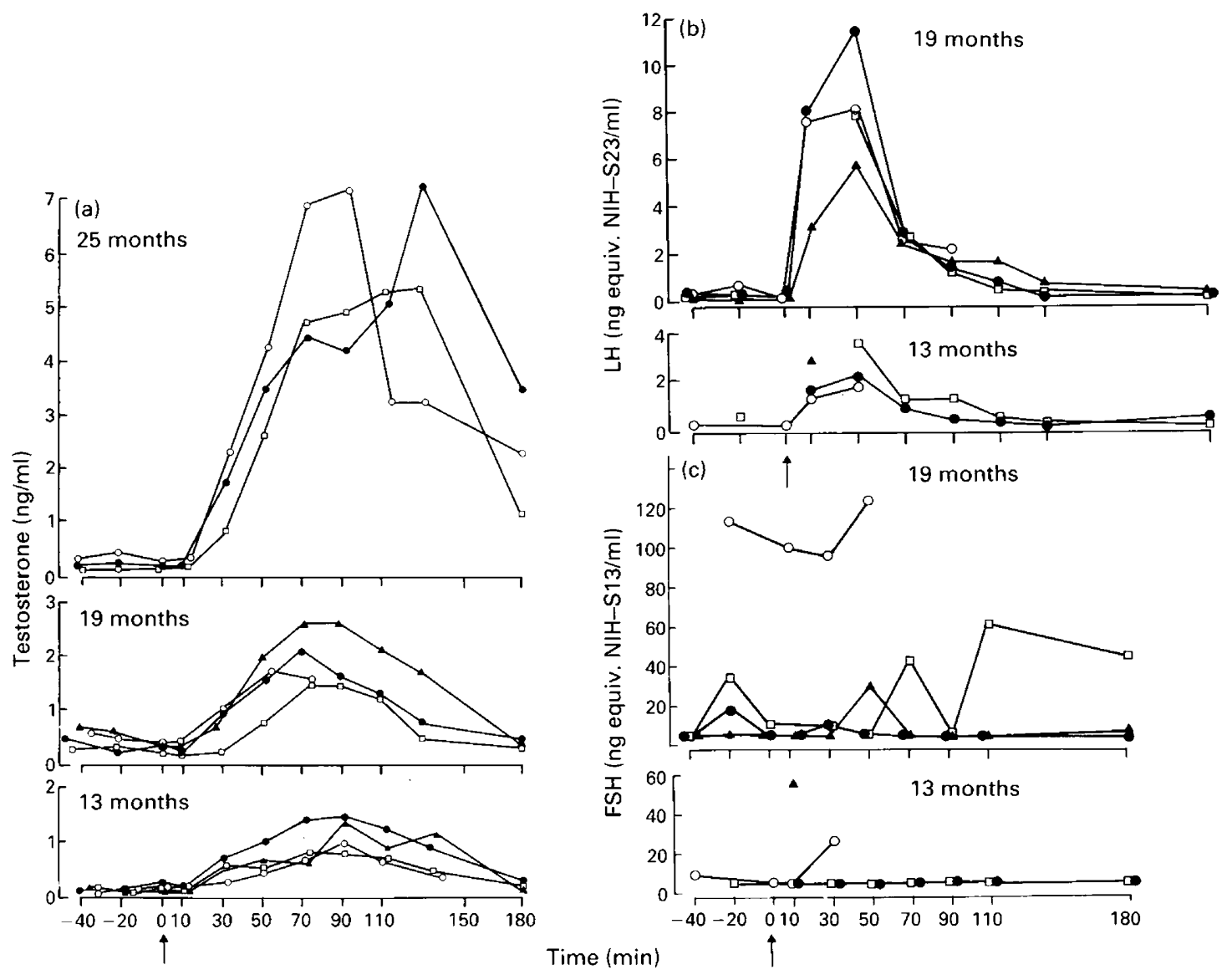

Fig. 3. Plasma concentrations of (a) testosterone, (b) LH and (c) FSH measured in groups of male tammars at different ages before and after the injection of $10 \mu \mathrm{g} \mathrm{LHRH}$ (arrow, $0 \mathrm{~min}$ ).

LH secretion increased after LHRH injection in the 13-month- and 19-month-old groups. No LH assays were possible for the 25 -month-old group in this experiment (Fig. $3 b$ ). There were no apparent differences between the resting plasma LH concentrations in the 13- and 19-month-old animals $(0.28 \pm 0.28$ and $0.20 \pm 0.14 \mathrm{ng} / \mathrm{ml}$, respectively) and peak values were reached $30 \mathrm{~min}$ after the LHRH injection. Peak LH concentrations of the 19 -month-old animals $(8.31 \pm 2.02 \mathrm{ng} / \mathrm{ml})$ were markedly increased in comparison with those of 13-month animals $(2.46 \pm 0.82 \mathrm{ng} / \mathrm{ml})$.

Basal FSH concentrations were $3.67 \pm 1.89$ and $21.0 \pm 32.48 \mathrm{ng} / \mathrm{ml}$ at 13 and 19 months respectively (Fig. 3c). The pattern of FSH release did not appear to change in response to the LHRH challenge. 
Experiment 2. Plasma LH and FSH concentrations before and after LHRH administration to 3 peripubertal ( 20 month) and 3 adult ( 25 months) males are shown in Fig. 4. Basal levels of LH in the preinjection samples were similar in both groups $(0.43 \pm 0.18 \mathrm{ng} / \mathrm{ml}$ at 20 months and $0.58 \pm 0.25 \mathrm{ng} / \mathrm{ml}$ at 25 months). Animals in both groups had exhibited peak concentrations of $\mathrm{LH}$ $(9 \cdot 0 \pm 2 \cdot 18$ and $7 \cdot 86 \pm 1.41 \mathrm{ng} / \mathrm{ml}$, respectively) by $30 \mathrm{~min}$ after injection of LHRH. In 2 of the 20-month animals, the $\mathrm{LH}$ concentration returned to basal values by $180 \mathrm{~min}$ after injection, but in the third animal LH concentration remained well above basal values at that time. All 3 of the 25 -month animals had LH values well above basal levels at $180 \mathrm{~min}$ after injection.

(a) 20 months
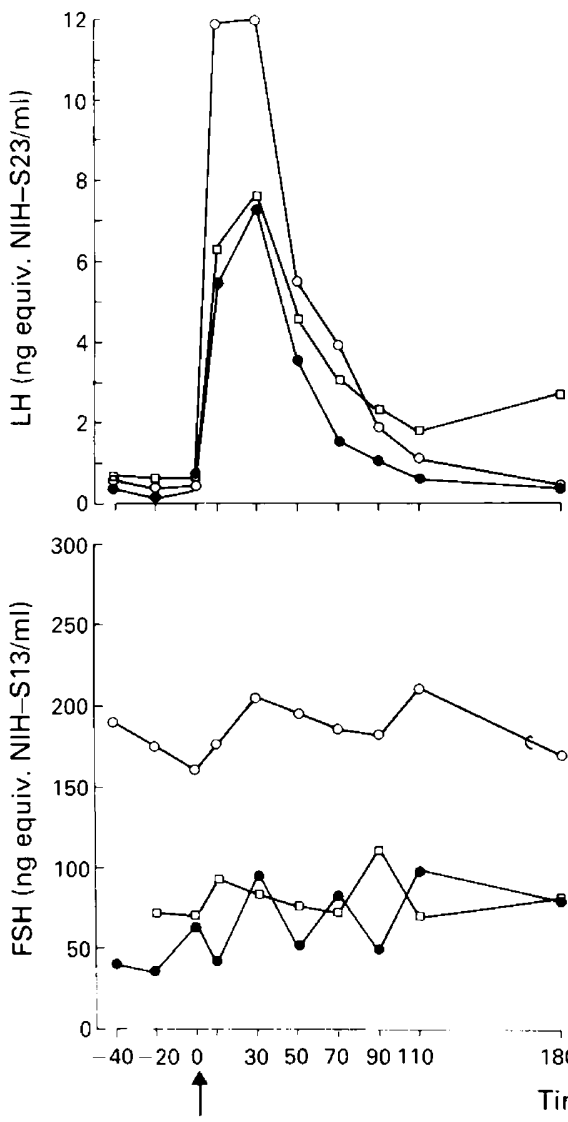

(b) 25 months
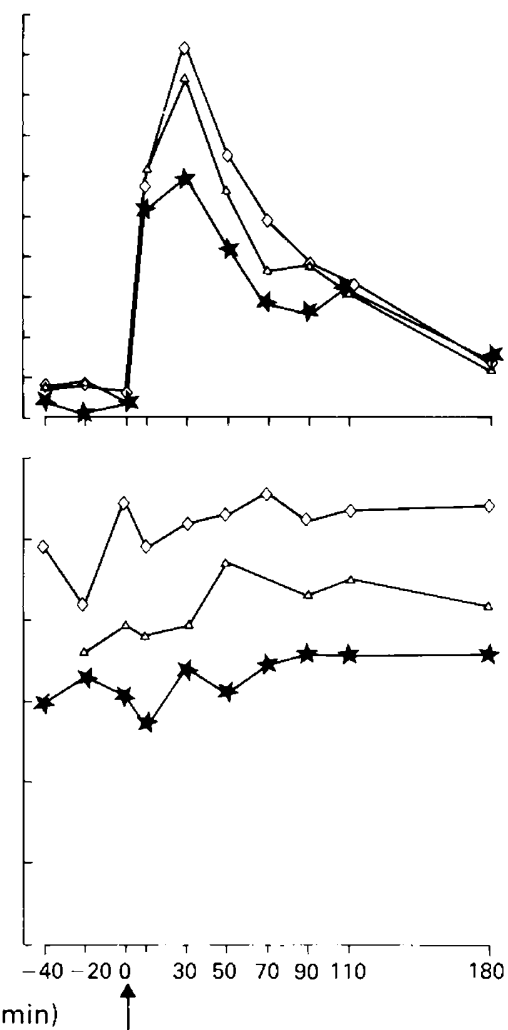

Fig. 4. Plasma LH and FSH concentrations measured in animals (a) 20 and (b) 25 months of age before and after injection of $10 \mu \mathrm{g}$ LHRH (arrow, $0 \mathrm{~min}$ ).

Mean basal FSH concentrations were higher at 25 months $(193.05 \pm 40.21 \mathrm{ng} / \mathrm{ml})$ than at 20 months $(94.40 \pm 55 \cdot 18 \mathrm{ng} / \mathrm{ml})$ and there was no increase in response to LHRH injection in either group. In one of the 20-month animals the preinjection concentration of FSH was similar to those measured in 25-month animals while the FSH concentrations measured in the other two 20-month animals were intermediate between those in the 19-month group of Exp. 1 and adult levels.

Basal and peak concentrations of LH in the 20-month group in Exp. 2 and the 19-month group in Exp. 1 were similar, demonstrating that there were no differences in plasma concentrations measured due to sampling from the jugular or the tail vein. Therefore the results of both experiments were pooled for the Discussion. 


\section{Discussion}

Marked changes occur in the morphology of the testis in tammar wallabies during the course of sexual maturation (Fig. 2). Testicular growth follows a logarithmic curve closely correlated to increasing body weight (Fig. 1). A similar logarithmic growth curve for testicular volume and a high correlation between testicular growth and increasing body weight have been recorded in other mammals (Abdel-Raouf, 1960; Attal \& Courot, 1963). This study confirms the data of Inns (1982) that spermatogenesis in tammars begins at 18-20 months of age, which is 10-12 months after pouch exit. This latter period is similar to the time between birth and puberty in males of several eutherian ruminants (Roberts, 1971).

Resting concentrations of testosterone in plasma were similar in each age group, but the response to LHRH injection was greater in both magnitude and duration in the mature wallabies ( 25 months) than in the young animals (13 months), with an intermediate response at 19 months. Resting concentrations of LH in plasma were similar in each group, but basal levels of FSH were highest in the 25-month group, intermediate in the 19- and 20-month groups and lowest in the 13-month animals. There was no response of FSH to LHRH injection in any group. However, the response of $\mathrm{LH}$ to LHRH injection in 19- and 20-month groups was greater than in the 13-month group, but equal to that of the adult group ( 25 months). This result provides evidence that the hypothalamic-pituitary axis was fully mature at 19 months at the onset of puberty, but that the testicular responsiveness to pituitary LH matured later, before 25 months. Chantaraprateep \& Thibier (1979) found that immature bulls showed a significantly lower testosterone response than did mature bulls to LHRH injection but had a greater LH response, indicating that the testes have only a limited capacity to secrete testosterone before puberty.

In the present study Wallaby 466 ( 19 months old), with all stages of spermatogenesis present in the germinal epithelium, had higher concentrations of testosterone than did the others in that group after injection of LHRH. Even though spermatogenesis was fully established in this wallaby its testosterone response was still considerably less than that of the 25 -month-old wallabies. Whether this observation has any biological significance remains to be seen, but our results and those of Inns (1982) show that, while about half of the animals studied at 18,19 or 22 months have full spermatogenesis, all at 24 and 25 months of age have full spermatogenesis and epididymal spermatozoa.

Female tammars are highly synchronized seasonal breeders, responsive to photoperiod (Tyndale-Biscoe \& Renfree, 1987), whereas spermatogenesis is continuous in male tammars (Hearn, 1975; Inns, 1982) and testicular volume shows no seasonal variation (Hearn, 1975). Plasma testosterone concentrations increase in wild populations of male tammars during the breeding season (Inns, 1982), whereas in isolated groups of captive male tammars (Catling \& Sutherland, 1980), neither age nor season changed resting testosterone concentrations. The presence of female wallabies in the wild population, with their highly synchronized seasonal oestrous activity, may stimulate this increased testosterone concentration in males during the breeding season. If season does influence the response even in isolated tammars, the difference in testosterone responses measured in the present study between the 25 -month-old wallabies (treated during the breeding season) and 19-month-old wallabies (treated in the non-breeding season), may be exaggerated. The immature group (13 months) were injected with LHRH at the same time of the year as the 25 -month animals, and so there is unlikely to be a seasonal effect involved when comparing results from these two groups.

In summary, these results show that the response of male tammars to LHRH injection as measured by increases in LH and testosterone changes in both magnitude and duration with increasing age, with no further increases in LH response to LHRH injection after 19 months but a distinct increase in testosterone response between 19 and 25 months, indicating that the hypothalamic-pituitary axis was fully functional at the onset of puberty, earlier than the pituitarytesticular axis. Puberty in male tammars begins between 19 and 20 months and is complete by 25 months of age. 
We thank L. Ellis, S. C. Williams and S. Wernberg-Moller for technical assistance; and Mrs S. Williams for secretarial help. This study was supported by a Murdoch University Special Research Grant and by Australian Research Grants Scheme Program Grant A1851504P. The animals were held under the terms of permit No. 84-28 from Department of Conservation, Forests and Lands, Victoria, Australia.

\section{References}

Abdel-Raouf, M. (1960) The post natal development of the reproductive organs in bulls with special reference to puberty. Acta endocr., Copenh., Suppl. 49, 1-109.

Alcorn, G. (1976) Ovarian development in the tammar wallaby. Ph.D. thesis, Macquarie University, Sydney.

Arslan, M., Mahmood, S., Khurshid, S., Naqvi, S.M.S., Afzal, M.A. \& Baig, S.M. (1986) Changes in circulating levels of immunoreactive Follicle Stimulating Hormone, Luteinizing Hormone and testosterone during sexual development in the rhesus monkey, Macaca mulatta. J. med. Primatol. 15, 351-359.

Attal, J. \& Courot, M. (1963) Devélopment testiculaire aete établishment de la spermatogenè chez le taureau. Annls Biol. anim. Biochim. Biophys. 3, 219-241.

Berger, M., Jean-Faucher, C., de Turckheim, M., Veyssiere, G. \& Jean, C. (1981) Pituitary Luteinizing Hormone and Follicle-Stimulating Hormone from birth to adulthood in male rabbit. Changes in the pituitary responsiveness to LHRH injection. Hormone Res. 15, 242-251.

Bronson, F.H. \& Risman, E.F. (1986) The biology of puberty. Biol. Rev. 61, 157-195.

Catling, P.C. \& Sutherland, R.L. (1980) Effect of gonadectomy, season, and the presence of females on plasma testosterone, luteinizing hormone, and follicle stimulating hormone levels in male tammar wallabies (Macropus eugenii). J. Endocr. 86, 25-33.

Chantaraprateep, P. \& Thibier, M. (1979) LH and testosterone responses to gonadoliberin (LRH) treatment in young bulls prior to and during puberty. Annls Biol. anim. Biochim. Biophys. 19, 637-646.

Coyotupa, J., Parlow, A.F. \& Abraham, G.E. (1972) Simultaneous radioimmunoassay of plasma testosterone and dihydrotestosterone. Analyt. Lett. 5, 324-335.

Evans, S.M., Tyndale-Biscoe, C.H. \& Sutherland, R.L. (1980) Control of gonadotrophin secretion in the female tammar wallaby, Macropus eugenii. J. Endocr. 86, 13-23.

Hearn, J.P. (1975) The role of pituitary in the reproduction of the male tammar wallaby, Macropus eugenii. J. Reprod. Fert. 42, 399-402.

Inns, R.S. (1982) Seasonal changes in the accessory reproductive system and plasma testosterone levels of the male tammar wallaby, Macropus eugenii, in the wild. J. Reprod. Fert. 66, 675-680.

Lee, V.W.K., Bremner, W.J., Cumming, I.A., de Kretser, D.M. \& Findlay, J.K. (1981) Effects of LH-RH infusion, castration and cryptorchidism on gonadotrophin and testosterone secretion in developing rams. J. Reprod. Fert., Suppl. 30, 111-118.
Lincoln, G.A. (1978) Plasma testosterone profiles in male macropodid marsupials. J. Endocr. 77, 347-351.

O, W-S., Short, R.V., Renfree, M.B. \& Shaw, G. (1988) Primary genetic control of somatic sexual differentiation in a mammal. Nature, Lond. 331, 716-717.

Ojeda, S.R. \& Urbanski, H.F. (1988) Puberty in the rat. In The Physiology of Reproduction, pp. 1699-1737. Eds E. Knobil \& J. Neill. Raven Press, New York.

Plant, T.M. (1988) Puberty in primates. In The Physiology of Reproduction, pp. 1763-1788. Eds E. Knobil \& J. Neill. Raven Press, New York.

Renfree, M.B., Shaw, G. \& Short, R.V. (1987) Sexual differentiation in marsupials. In Genetic Markers of Sex Differentiation, pp. 27-41. Eds F. P. Haseltine, M. E. McClure \& E. H. Goldberg. Plenum Press, New York.

Roberts, S.J. (1971) Veterinary Obstetrics and Genital Diseases (Theriogenology). Edwards Bros, Inc., Ann Arbor.

Rosendahl, W., Haars, H. \& Gupta, D. (1984) Studies on the age-dependent nature of the response to $\mathrm{LHRH}$ given via different routes. Psychoneuroendocrinology 9, 179-187.

Schanbacher, B.D. (1982) Hormonal interrelationships between hypothalamus, pituitary and testis of ram and bulls. J. Anim. Sci. 55, 5667 .

Shaw, G., Renfree, M.B. \& Short, R.V. (1989) Primary genetic control of sexual differentiation in marsupials. Aust. J. Zool. (in press).

Short, R.V., Renfree, M.B. \& Shaw, G. (1988) Sexual development in marsupial pouch young. In Development of Young Marsupials: Models for Biomedical Research, pp. 200-210. Eds C. H. Tyndale-Biscoe \& P. A. Janssens. Springer-Verlag, Berlin.

Spratt, D.I. \& Crowley, W.F. (1988) Pituitary and gonadal responsiveness is enhanced during GnRHinduced puberty. Am. J. Physiol. 254, 652-657.

Sumbung, F.P., Williamson, P. \& Carson, R.S. (1987) Response of prepubertal ewes primed with monensin or progesterone to administration of FSH. J. Reprod. Fert. 81, 317-325.

Sutherland, R.L., Evans, S.M. \& Tyndale-Biscoe, C.H. (1980) Macropodid marsupial luteinizing hormone: validation of assay procedures and changes in plasma levels during the oestrous cycle in the female tammar wallaby, Macropus eugenii. J. Endocr. 86, 1-12.

Tyndale-Biscoe, C.H.\& Renfree, M.B.(1987) Reproductive Physiology of Marsupials. Cambridge University Press, $476 \mathrm{pp}$.

Received 20 June 1989 